\title{
The Impact of Major Sporting Events on the Economy and the People of a Developing Region The Case of the 2010 FIFA World Cup Tournament
}

This paper explores the expected economic and social impact of the 2010 FIFA World

Cup on South Africa. It investigates the justification for spending of public funds towards the upgrading and building of sports stadia in South Africa as a developing country, and offers an empirical survey regarding probable match attendance and ticket prices.

Maléne Campbell and Kedibone Phago

Maléne Campbell is a senior lecturer in the Department of Urban and Regional Planning at the University of the Free State, South Africa.

Kedibone Phago is lecturer in the Department of Public Administration and Management at the University of South Africa, South Africa.

\section{Introduction}

Research conducted on events held in the United Kingdom (UK) found that nine sporting events generated an additional expenditure of more than $£ 1.45$ million, which shows how staging major sporting events can benefit a country as a whole. ${ }^{1}$ The 1994 FIFA World Cup in America attracted 3,5 million record numbers of spectators. ${ }^{2}$ Yet, will South Africa benefit from the 2010 FIFA World Cup, seeing that the economic and socio-economic advantages of major sporting events are not implicit? ${ }^{3}$ And are economic benefits the only benefits, or is there a bigger picture?

Substantial sums of public funds are spent in bidding for and the hosting of a mega sport event. The hosting has a strong symbolic function that invokes a sense of community, excitement and emotion. ${ }^{4}$ The hosting of sports events is regarded as part of a broader tourism strategy - cities hosting major sporting events have the unique opportunity to market themselves ${ }^{5}$ and to showcase the uniqueness of these local communities to the outside world. ${ }^{6}$ The successful hosting of the 1995 Rugby World Cup as well as the 2003 Cricket World Cup made it possible to create a new image and identity for South 
Africa. ${ }^{7}$ According to Hoeane ${ }^{8}$ the Springbok 2007 Rugby World Cup victory revealed the yearning for unity among South Africans - this victory "has resonated deeply with the majority and it has given them a tangible sense of much needed pride." 9

According to Owen, ${ }^{10}$ however, no empirical evidence has been found of any significant economic impact of any large-scale sporting event such as the increase in household income:

The true economic benefits are typically far less than the numbers touted by promoters. Cities and countries would be well advised to more thoroughly evaluate promises of a windfall from hosting a sports mega-event such as the World Cup and Olympics before committing public resources to such an event. ${ }^{11}$

Before 1980 sporting events such as the Olympics were a financial and administrative burden to the host - Montreal, for example, the host of the 1976 Olympics, made a loss of $£ 692$ million and Munich, the 1972 host, made a loss of $£ 178$ million. This changed in 1984 when Los Angeles made a profit of $£ 215$ million.

Only recently did governments realise that they are publicly accountable for investing community resources in venues or sporting events and have to show how it will provide a return for the community. ${ }^{12}$ Therefore the aim of this article is to evaluate the impact that hosting the 2010 FIFA World Cup would have on the host country, South Africa. The article provides a theoretical background to regional planning in order to develop a good understanding of the topic. Influential contributions to developmental thinking in regional planning and regional development are discussed, various aspects of regional planning are highlighted, as well as the theories of regional development applicable to this article. Case studies on the hosting of sporting events are reviewed, as well as the importance of infrastructure provision in a region. This is followed by a discussion of the empirical research and, finally, the conclusion.

\section{Regional Planning}

Glasson ${ }^{13}$ argues that regional planning tends to be somewhat of an intruder in the planning fraternity since its role in the planning framework is not very clearly defined, nor are its aims fully worked out or generally agreed upon. Even though there is no clear or well-defined definition of regional planning, many scholars have endeavoured to formulate different definitions of what regional planning involves.

According to Gertler, ${ }^{14}$ the concept of regional planning can be clearly defined as

\begin{abstract}
a process, based on law and undertaken by a form of responsible government directed towards influencing development, private or public, in a matter that results in the areas where people settle, and establish regional communities, in the best environment and the soundest use of resources that civilization is capable of effecting.
\end{abstract}

Friedmann and Alonso ${ }^{15}$ argue that, in an attempt to circumscribe the field of regional planning, three separate meanings can be distinguished: regional planning is made synonymous with regional development policy at national level ('balanced integration'); with a process of decision-making and design in the elaboration of investment projects at regional level; and with economic development programmes for sub-national areas.

In addition, Glasson ${ }^{16}$ is of the opinion that regional planning can perhaps best be seen as a planning response to the regional issues that 
Figure 1: Host Cities

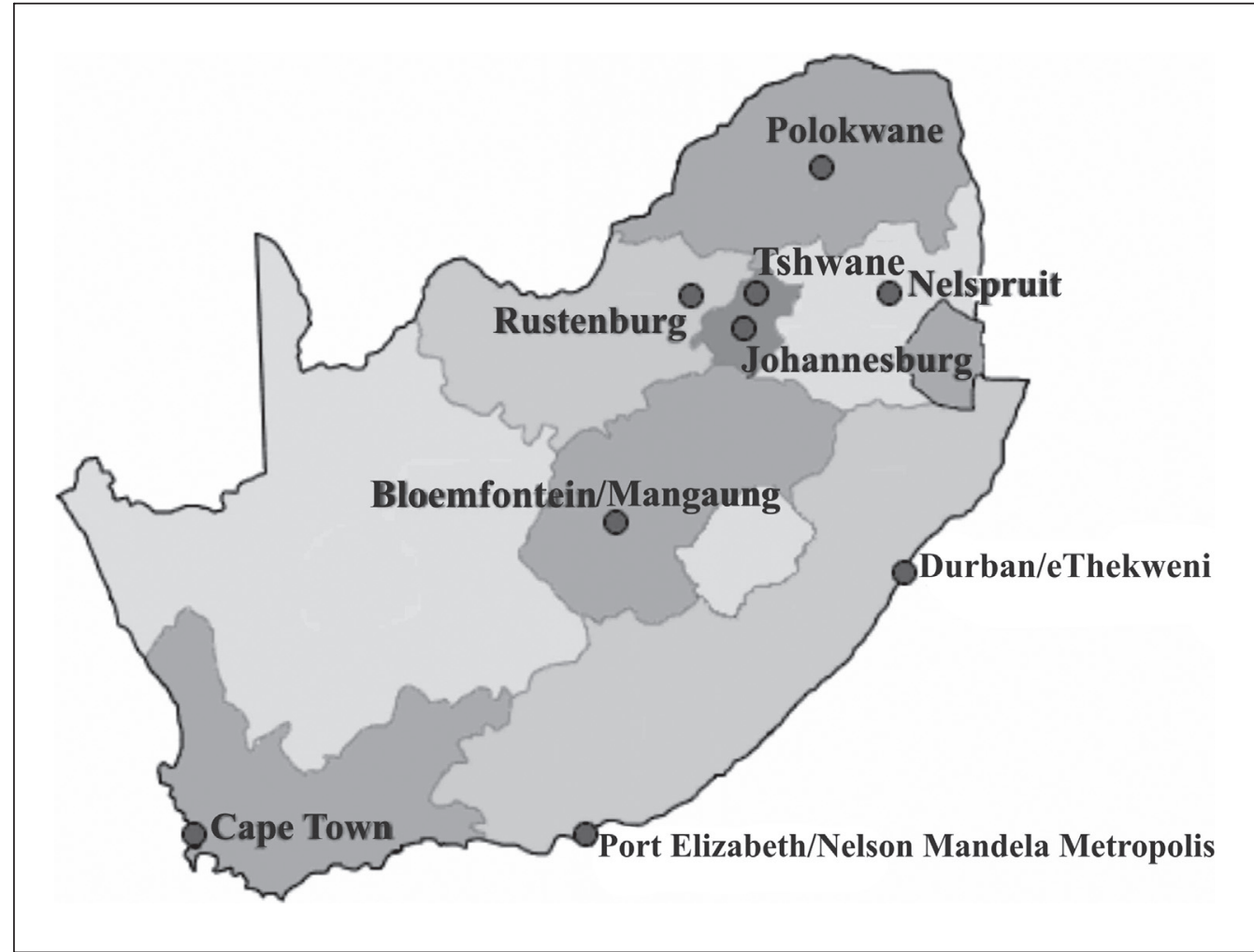

Source: Project 2010, 2007

appear most pressing in any particular country at a specific point in time, where the countdown to 2010 in South Africa immediately comes to mind. It has also been pointed out that the focus of regional planning for a specific area depends on certain aspects, since it is an extension of local planning, dealing particularly with these matters - the movement of and distribution of population and employment, the complex interaction of social and economic needs, the provision of major recreational facilities and the main communication network.

Regional planning is the process of formulating and clarifying social objectives in the ordering of activities in supra-urban space. ${ }^{17}$ Community development and national unity can be two examples of such social objectives in South Africa when hosting the 2010 FIFA World Cup. In a spatial context, regional planning has two vital basic components, namely regional balance and balanced growth. Thus, the two basic elements differ, since it has been argued that balance does not imply equality, uniformity or conformity, but equality of opportunities for each region..$^{18}$ However, regional balance means that all the regions in South Africa should have equal access to resources in order to develop further, and this goal needs to be pursued in regional planning. In the context of this article, it means that all the host cities in previously disadvantaged regions of Polokwane, Nelspruit, Rustenburg, Nelson Mandela Metropolis (Port 
Elizabeth) and Bloemfontein/ Mangaung (see Figure 1) should be given equal opportunities, rather than concentrating on Johannesburg, Tshwane, eThekwini and Cape Town.

Glasson $^{19}$ argues that underdeveloped regions often cover a large proportion of the area of the countries concerned, although their population may be quite small or scattered. In other words, these regions are chiefly dependent on primary occupations, particularly agriculture, forestry and fishing, which may be affected detrimentally by various factors such as a low level of productivity, the exhaustion of natural resources and outdated technology. Friedmann and Alonso ${ }^{20}$ argue that, "by definition, a depressed area is one in which economic growth has lagged and in which the population's level of welfare is substantially lower than that in other regions. The reason for the region's backwardness is that rapid growth has located elsewhere." Glasson ${ }^{21}$ states that depressed industrial regions went through the process of industrialisation in the 19th century and are now suffering from an over-reliance on declining and stagnating industries. On the other hand, Farrar ${ }^{22}$ argues that depressed regions are affected by the location disadvantage of regional development referred to as declining regions. From a regional planning perspective, these (declining) regions are characterised by loss of services, employment and population. In addition, these regions experience an influx of low-income households and a polarisation towards cities in terms of jobs, incomes and infrastructure, while communities with a concentration of disadvantages find themselves excluded in certain global cities that are economically beyond their reach.

The district municipalities that include the towns of Polokwane, Nelspruit and Rustenburg can also be identified as formal economic regions depending mainly on primary activities (agriculture, mining and forestry), as well as being underdeveloped regions, and Port Elizabeth within the Nelson Mandela Metropolis may be considered a depressed industrial region since the Eastern Cape has a lower Human Development Index of 0,603 in comparison to the 0,727 of both Gauteng and the Western Cape. ${ }^{23}$ The district municipalities that include Johannesburg, Tshwane, Cape Town, eThekwini and Bloemfontein/ Mangaung do not fall under any of the problem region categories identified by Glasson and it were classified as developed regions in comparison to the former regions.

\section{Case Studies}

Tourism is regarded as a growth catalyst that generate income and employment opportunities, but in South Africa the "market potential of domestic tourism has been downplayed in favour of international tourism". ${ }^{24}$ Therefore an effort needs to be made to cultivate the market potential of domestic tourism in 2010 as well. From a case study of the Two Oceans Marathon in Cape Town done by Kotze ${ }^{25}$ it can be deduced that if developing countries do not have the capital to host mega-sporting events they should consider hosting smaller events. The hosting of a small-scale sport event might also deliver economic benefits without placing the burden of additional costs upon the host community. ${ }^{26}$ These events will "generate much-needed income and contribute towards the re-imaging of the hosting city or country". ${ }^{27}$

The 1992 Barcelona Games and the 2000 Sydney Games were two of the most successful mega-events ever to be hosted. In both these cases the supporting infrastructure and expenditures on urban regeneration contributed towards the development of the region and the country. ${ }^{28}$ However, after spending large amounts of capital on stadia, it must be ensured that these 
stadia can be used in a profitable manner. The Stade de France built in Paris for the 1998 FIFA World Cup has since hosted many major sporting contests due to its multi-purpose capabilities, ${ }^{29}$ including the 2007 Rugby World Cup. A South African example is the Nelson Mandela Bay Stadium in Port Elizabeth that is planned to be such a multi-purpose stadium ${ }^{30}$ that can stage contests for sporting events other than soccer as well after 2010. The Melbourne Sport and Aquatic Centre in Melbourne, Australia is an example of a venue that offers facilities for elite and community sport in swimming, basketball, volleyball, table tennis, squash and badminton. This facility brings people from different sporting backgrounds together. ${ }^{31}$

\section{Provision of Infrastructure}

The total accessibility of a region by means of its infrastructure plays an important role in the development of the tourism industry and the distribution of facilities, goods and people in the area. A good transport and communication network supports local economic activities - without the ability to conveniently get to and move around a region, it is difficult to stimulate growth.

\section{Infrastructure Financing in South Africa}

The staging of major sports events normally involves the host contributing towards the costs. Whether such a contribution is justified, depends on the economic benefits generated in the local economy. ${ }^{32}$ According to the South African Minister of Finance's Budget Speech of 2007, the national government has contributed R17.4 billion towards the 2010 FIFA World Cup. Of this, R8.4 billion is going to be spent on the building of five new stadia and the upgrading of five existing ones, the remaining $\mathrm{R} 9$ billion will be spent on the transport infrastructure. ${ }^{33}$
The host cities (see Figure 1 above) are to contribute a further R2.6 billion towards the costs of the stadia. ${ }^{34}$ In addition, the provincial governments are also making huge contributions, such as the Free State government that agreed to contribute towards the R64.5 million shortfall when the costs of upgrading the Free State stadium increased from R241 million to R305.5 million. ${ }^{35}$ The following stadia will be upgraded: Ellis Park in Johannesburg at a cost of R229 million, Kings Park in Durban (eThekwini) at a cost of R2.8 billion and Loftus Versfeld in Pretoria (Tshwane) at a cost of R98 million. The local municipalities are also contributing towards the upgrading such as Rustenburg where R20 million will be spent on the Royal Bafokeng stadium in Northwest. ${ }^{36}$ It seems that not only national government, but also the provincial and municipal governments are committed to the successful hosting of the 2010 FIFA World Cup in South Africa.

\section{Increased Capital Investment}

The upgrading of existing infrastructure in South Africa is a welcome injection for the construction industry that currently employs $5,4 \%$ of the work force ${ }^{37}$ and creates about 159000 new jobs annually. ${ }^{38}$ This improvement specifically to the transport infrastructure will benefit productivity in the long term and may lead to an increase in the GDP of up to R20 million. ${ }^{39}$

The Gauteng Rapid Rail Link, a R25 billion project $^{40}$ to be completed in time for the 2010 FIFA World Cup is another example of the upgrading of infrastructure. This high-speed train will travel between Johannesburg, Tshwane (Pretoria) and Oliver Tambo International Airport, unfortunately excluding the low-cost housing areas such as those found in Soweto, at Orange Farm and at Katorus. Therefore workers travelling from these areas on the urban periphery to the inner city will not 
benefit from this infrastructure investment. ${ }^{41}$ The Gauteng Rapid Rail Link is one of ten large-scale proposals being developed by the Gauteng Provincial Government as part of their Strategic Development Initiative Programme. These projects will comprise technology, transport, manufacturing and tourism expansion initiatives in Johannesburg and other key areas of the province. It will also have a significant impact on the economy of the region, ${ }^{42}$ although provision of an infrastructure does not necessarily lead to the eradication of poverty. ${ }^{43}$

\section{Empirical Research}

A case study was done of the university town of Potchefstroom with the aim to determine the economic benefits of the 2003 Cricket World Cup for the host community. ${ }^{44}$ It was found that the majority (19\%) of the spectators that attended the three matches researched were university and technikon students. ${ }^{45}$ The following section discusses a quantitative study done among 100 postgraduate students of the Building Science Group of the University of the Free State to determine if they would attend matches during the 2010 FIFA World Cup, how much they were willing to pay for a ticket, as well as how far they would be willing to travel to watch matches.

Structured questionnaires were circulated among the target group. In terms of their income, only $4 \%$ of the respondents indicated that they were employed full time and earned R5 000 or more per month, while the majority of the respondents (96\%) were studying full time. Most of the respondents (86\%) indicated that they planned to attend matches, while only one respondent indicated that he/she would watch the matches on television instead.

The response to the question, "How much are you willing to pay for a match ticket during the 2010 World Cup Soccer", is summarised in Figure 2 below. It is clear from the data that the majority of the students interviewed were willing to pay R100 or less for a ticket, while ticket prices for the 2006 FIFA World Cup in Germany

\section{Figure 2 Amounts Respondents are Willing to Pay for Tickets}

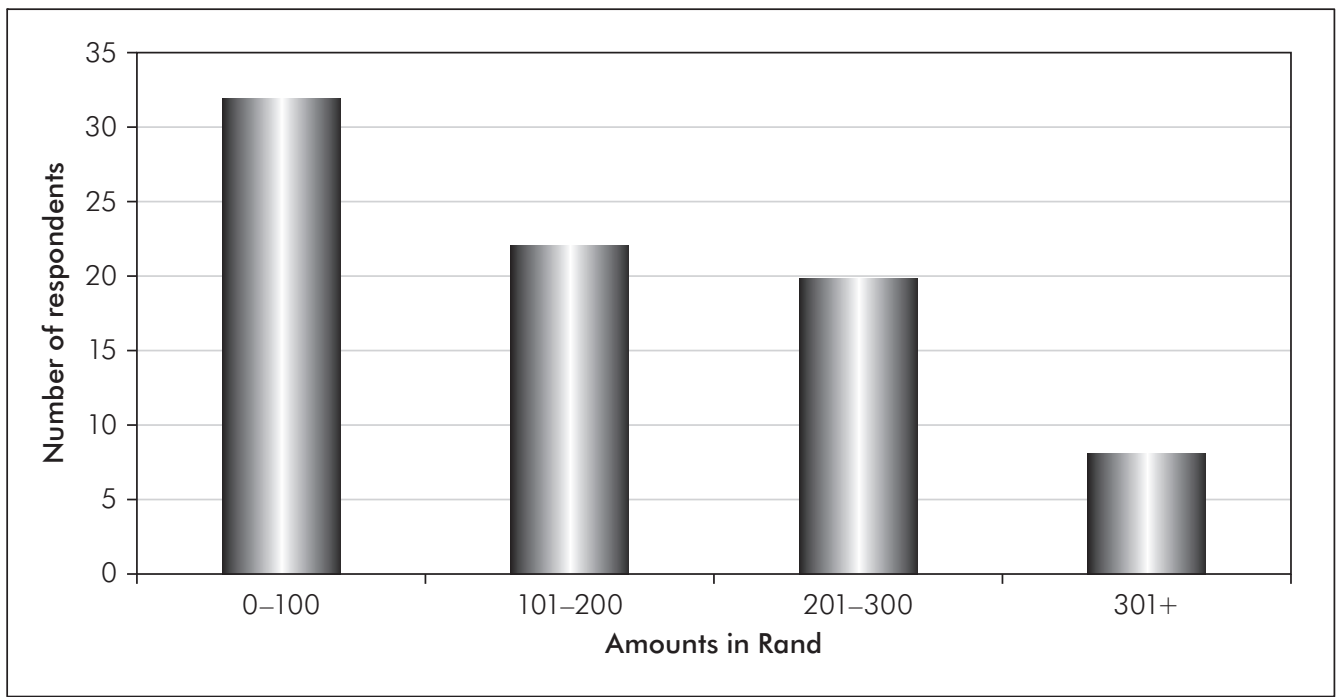


Figure 3 Distances Supporters are Willing to Travel for Matches

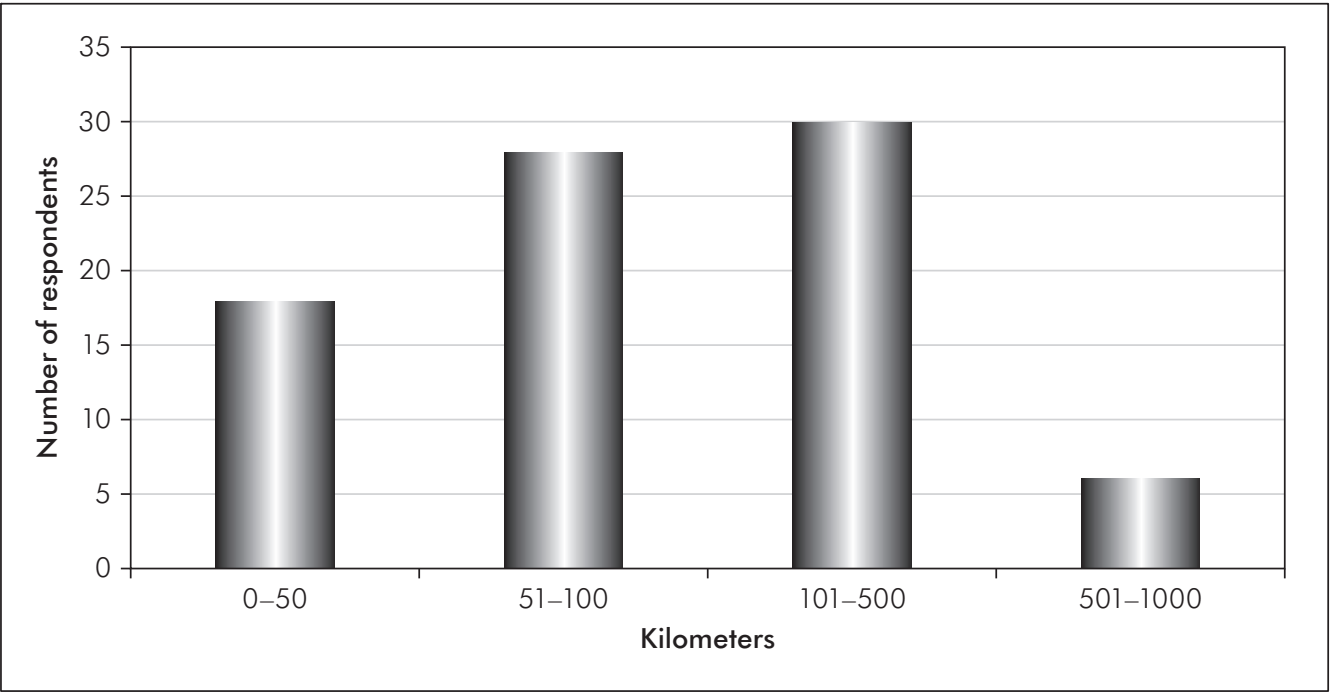

ranged between $\mathrm{R} 518$ ( 45 ) for a group match and R6 900 (600) for the final match. ${ }^{46}$ Only eight respondents indicated that they were willing to pay more than R300 ( 26) for a ticket and some of them would be the only ones that could afford tickets if the asking prices were to be the same for the 2010 FIFA World Cup as they were for the 2006 FIFA World Cup.

The distances from Bloemfontein to the big centres in South Africa where the major matches are most likely to be played are as follows:

- Pretoria (Tshwane) $475 \mathrm{~km}$

- Johannesburg $417 \mathrm{~km}$

- Durban $667 \mathrm{~km}$

- Cape Town 998km.

The target group was asked how far they were willing to travel to watch a match in 2010 (see Figure 3 below). From this it is clear that 30 of the 86 respondents (34.9\%) indicated that they would attend matches were willing to travel as far as Johannesburg and Pretoria (Tshwane), while $6(7 \%)$ were willing to travel as far as Cape Town.
The three teams mainly supported by South Africans are the South African, English and Brazilian sides. ${ }^{47}$ Although the majority of the respondents, 78 out of 86 (90.7\%), indicated that they would attend other matches than those played by the South African, English and Brazilian sides as well. However, a very low percentage of the respondents, only $16 \%$, indicated that they attended the 1996 Africa Cup of Nations hosted in South Africa. This could be explained by the fact that most of the respondents were younger than ten years in 1996 and were at that stage dependent on parents or adults to accompany them.

\section{Conclusion}

The staging of major sports events normally involves the host making a contribution towards the costs. Whether such a contribution is justified depends partly on the economic benefits generated in the local economy. The national government is contributing R17.4 
billion towards the 2010 FIFA World Cup Soccer Tournament and transport infrastructure, while the ten host cities are to contribute a further R2.6 billion towards the costs of the stadia. This will be a welcome injection for the construction industry and the improvement to the transport infrastructure specifically will benefit productivity in the long term.

The success of the 1994 FIFA World Cup in the US is ascribed towards the record numbers of spectators. However, the majority of the target group interviewed for this article are willing to pay R100 ( 10 ) or less for a ticket, while ticket prices for the 2006 FIFA World Cup in Germany ranged between R450 ( 45 ) for a group match and R6 000 ( 600 ) for the final match.

The question therefore arises whether enough local spectators will be able to attend matches if the prices of the tickets are out of their reach. In order to cultivate the market potential of domestic tourism it is therefore proposed that ticket prices should be adjusted to accommodate the local people, since the amount of ticket sales will also contribute towards the financial success of the tournament.

\section{Notes and References}

1 London 2012, 'Report Highlights Economic Benefits of Hosting Sport', in London 2012, www.london2012.org/ en/news/archive, accessed 25 January 2005.

2 E Loots, 'Ekonomiese Voordele van 2010 nié so Vanselfselfsprekend', in G Coetzee, Volksblad Aktueel, 16 Januarie 2007, p 9.

3 Ibid.

4 CK Lee and T Taylor, 'Critical Reflections on the Economic Impact Assessment of a Mega-Event: The Case of the 2002 FIFA World Cup', Tourism Management, vol 26, 2005, pp 595-603.

5 C Gratton, N Dobson and S Shibili, 'The Economic Importance of Major Sports Events: A Case Study of Six Events', Managing Leisure, vol 5, 2000, p 19.

6 H Westerbeek, A Smith, P Turner, P Emery, $C$ Green, and $L$ van Leeuwen, L. Managing Sport Facilities and Major Events. London and New York: Routledge, 2006.

7 N Kotze, 'Cape Town and the Two Oceans Marathon: The Impact of Sport Tourism', Urban Forum, vol 17, no 3, July-September 2006, p 291.

8 T Hoeane, 'It's Time to Start Talking About Race', Sunday Times, 28 October 2007.

9 Ibid.

10 JG Owen, 'Estimating the Cost and Benefit of Hosting Olympic Games: What can Beijing Expect from its 2008 Games?' The
Industrial Geographer, vol 3, no 1, 2005, p 15.

11 VA Matheson and RA Baade, 'MegaSporting Events in Developing Nations: Playing the Way to Prosperity?' College of the Holy Cross, Department of Economics Faculty Research Series, Working Paper no 04-04. Worcester, Massachusetts, 2004, p 21.

12 Westerbeek et al. 2006.

13 J Glasson, 'Introduction to Regional Planning: Concepts, Theory and Practice', London: UCC Press, 1978, p 17.

14 L Gertler, 'Regional Planning in Canada: A Planner's Testamen', Canada: Harvest House, 1972, p 46.

15 J Friedman and W Alonso (eds), Regional Development and Planning: A Reader, Massachusetts: The M.ITT Press, 1964, p 60.

16 Glasson 1978, p 26.

17 Friedman and Alonso 1964, p 60.

18 Glasson 1978, pp 29-30.

19 Ibid.

20 Friedman and Alonso 1964, p 76.

21 Glasson 1978, p 197.

22 A Farrar, 'Housing and Regiona Development', www. Community Housing org.au/Housingconference, accessed on 22 September 2005.

23 CJ Meintijes, Guidelines to Regional Socio-economic Analysis, Development
Bank of Southern Africa. Halfway House: Development Information Business Unit, 2001, p 10.

24 M Saayman, A Saayman and JA Rhodes, 'Domestic Tourist Spending and Economic Development: the Case of the North West Province', Development Southern Africa, vol 18, no 4, October 2001.

25 Kotze 2006.

26 G Allan, S Dunlop and K Swales, 'The Economic Impact of the Old Firm Football Spectators as Sports Tourists: An InputOutput Application to Glasgow and Scotland', Regional Studies Association Conference: Regions in Focus, Lisbon, Portugal. 2-5 April 2007. http:// www.regional-studies-assoc.ac.uk/ events/020407papers.asp. Accessed on 21 February 2008.

27 Ibid.

28 HR Bohlman, 'Predicting the Economic Impact of the 2010 FIFA World Cup on South Africa', Department of Economics Working Paper Series, Working Paper 2006-11, Pretoria: University of Pretoria, 2006.

29 Ibid.

30 R Mohola, 'Builders Pile in PE Stadium Well Ahead of Schedule', Sowetan, 22 November 2007.

31 Westerbeek et al. 2006.

32 Gratton et al. 2000, p 17. 
33 Sake Volksblad, 22 Februarie 2007, p 12.

34 Ibid.

35 Anon., 'Stadium Upgrade: Residents to Score', Sowetan, 22 November 2007.

36 SABC News, 'Construction of North West 2010 Stadium Delayed', www.sabcnews. $\mathrm{com} / \mathrm{sport} / \mathrm{soccer}$. Accessed on 22 November 2007.

37 Statistics South Africa, Census in Brief. Report no 03-02-02 (2001), Pretoria: Statistics South Africa, 2003, p 62.

38 Loots 2007.

$39 \mathrm{HR}$ Bohlman and JH van Heerden, 'The Impact of Housing a Major Sport
Event on the South African Economy', Department of Economics Working Paper Series, Working Paper 2005-09, Pretoria: University of Pretoria, 2005, p 6.

40 Anon., 'Jhb se "9/11" maak plek vir Gautreinstasie', Volksblad, 5 Februarie 2007, p 5.

41 G Baeten, A Spithoven and L Albrechts, Mobiliteit: Landschap van Macht en Onmacht, Leuven: Acco, 2000, p 144.

42 M Campbell, M Ward and T Stewart, 'Towards the Integration of Housing with a Mass Transport System in the Greater Johannesburg Area', XXXIII IAHS World Congress on Housing, Transforming housing through design. 27-30 September 2005. Pretoria: South Africa.

43 Meintjies 2001, p 26

$44 \mathrm{C}$ du Plessis, 'The Economic Impact of the 2003 Cricket World Cup on Potchefstroom', Unpublished Master's degree dissertation. North West University, Potchefstroom Campus, 2004.

45 Ibid., p 88.

46 Soccerphile, World Cup 2006 Germany Tickets, www.soccerphile.com. Accessed 21 February 2007.

47 T Mokomatsili, Personal communication on the 2010 FIFA World Cup, Bloemfontein, 2007. 